\title{
Vitamins E and C Alleviate the Germ Cell Loss and Oxidative Stress in Cryptorchidism When Administered Separately but Not When Combined in Rats
}

\author{
Ayobami Oladele Afolabi, ${ }^{1}$ Olaolu Opeyemi Olotu, ${ }^{1}$ and Isiaka Abdullateef Alagbonsi ${ }^{2}$ \\ ${ }^{1}$ Department of Physiology, College of Health Sciences, Ladoke Akintola University of Technology, PMB 4000, Ogbomoso, Oyo, Nigeria \\ ${ }^{2}$ Department of Physiology, Faculty of Medicine, Kogi State University, PMB 1008, Anyigba, Kogi, Nigeria
}

Correspondence should be addressed to Isiaka Abdullateef Alagbonsi, easylat@gmail.com

Received 23 September 2012; Accepted 10 October 2012

Academic Editors: T. Irie and D. K. Miller

Copyright (c) 2012 Ayobami Oladele Afolabi et al. This is an open access article distributed under the Creative Commons Attribution License, which permits unrestricted use, distribution, and reproduction in any medium, provided the original work is properly cited.

\begin{abstract}
The antioxidant effects of vitamins $\mathrm{C}$ and $\mathrm{E}$ on cryptorchidism-induced oxidative stress were investigated in male Sprague-Dawley rats. Forty rats $(200-250 \mathrm{~g})$ were randomly divided in a blinded fashion into five groups $(n=8)$. Group 1 was sham operated and treated with vehicle (corn-oil, $10 \mathrm{~mL} / \mathrm{kg}$ ). Groups 2, 3, 4, and 5 were rendered unilaterally cryptorchid and treated with vehicle $(10 \mathrm{~mL} / \mathrm{kg})$, vitamin E solution $(75 \mathrm{mg} / \mathrm{kg})$, vitamin C solution $(1.25 \mathrm{~g} / \mathrm{kg})$, and combination of vitamin E $(75 \mathrm{mg} / \mathrm{kg})$ and vitamin $\mathrm{C}(1.25 \mathrm{~g} / \mathrm{kg})$ solutions, respectively. Germ cell count, superoxide dismutase (SOD), total protein (TP), and testicular weight (TW) were lower, but malondialdhyde (MDA) was higher in the cryptorchid rats than the sham-operated rats. When administered separately, vitamins $\mathrm{C}$ and $\mathrm{E}$ increased germ cell count, SOD, TP, and TW but did not reduce MDA in the cryptorchid rats when compared to the vehicle-treated cryptorchid rats. However, there was no significant difference in these parameters between vehicletreated and combined vitamins $\mathrm{C}$ - and E-treated rats. This suggests that vitamins $\mathrm{E}$ and $\mathrm{C}$ alleviate the germ cell loss and oxidative stress in cryptorchidism when administered separately but not when combined in rats.
\end{abstract}

\section{Introduction}

The vital roles of vitamins in the prevention of various deficiency diseases such as Beriberi, Pellagra, and Rickets have been elucidated. Recent studies have shown that the role of these micronutrients extends beyond the mere prevention of deficiency diseases to the maintenance of general good health in various organ systems [1]. The vital roles of micronutrients in the normal functioning of the central nervous system [2], cardiovascular system [3], respiratory system, and hepatic organ [4] have been extensively investigated. The beneficial effects of vitamins $\mathrm{E}$ and $\mathrm{C}$ have been largely attributed to their antioxidant properties, which tend to counteract the harmful effects of free radicals generated by the body's metabolic processes [5]. These antioxidant properties of the two vitamins have been extensively investigated individually $[6-8]$ and when combined $[9,10]$. Britton et al. [11] showed that vitamins $\mathrm{E}$ and $\mathrm{C}$ when combined have a synergistic effect, which potentiates their antioxidant actions. Combination of vitamins $\mathrm{E}$ and $\mathrm{C}$ has been found to be efficacious in alleviating the oxidative stress induced by exercise [12] and atherosclerosis [13].

Cryptorchidism results from the failure of the testis to descend from the abdominal region into the scrotal sac. It occurs naturally [14], can be induced experimentally [15], and may be unilateral or bilateral. It can be congenital, or acquired, whereby testes that were in scrotal position at birth later ascend [16, 17]. It usually results from hormonal abnormalities, which could be either deficiency or insensitivity to androgen or to antimullerian hormone [18]. Several studies have described low birth weight and preterm delivery as the major risk factors for cryptorchidism [19]. In prospective studies using similar and clearly defined criteria of cryptorchidism, the birth rate of cryptorchidism has varied between 1.6 and $9.0 \%$ in USA [20], Denmark $[21,22]$, Finland [21], Italy [23], India [24], Lithuania [25], 
UK [17, 26], and Malaysia [27]. It is the most significant risk factor for testicular cancer increasing the risk 2.5-11-fold [28]. Its aetiology is for the most part unknown and appears to be multifactorial [29].

Cryptorchidism induces apoptosis, cell death and large scale removal of germ cells from the seminiferous epithelium [30]. Recent studies have shown that testicular testosterone production is acutely reduced in a number of conditions like cryptorchidism, which is associated with reactive oxygen species (ROS) production and oxidative stress in the testis $[30,31]$. In most mammals, the testis is kept between $3-5^{\circ} \mathrm{C}$ below body temperature. A slight increase in temperature for a short or long period results in a rapid loss of mature germ cells. The increased testicular temperature in cryptorchidism has long been associated with increased testicular oxidative stress [15, 32, 33]. Moreover, cryptorchidism has also been shown to induce an increase in ROS, which correlated with increased germ cell apoptosis and alterations in the expression of a number of genes associated with energy and lipid metabolism, stress response, and redox reactions [34]. Testis tissue under increased temperature in vitro also showed an increased susceptibility to oxidative stress and germ cell apoptosis [35].

Since oxidative stress has been well reported as the major cause of many symptoms sequel to cryptorchidism, and vitamins $\mathrm{C}$ and $\mathrm{E}$ have been reported to possess antioxidant effects individually and when combined, studies on the antioxidant effects of these vitamins in cryptorchidisminduced oxidative stress were of interest to us. The present study was thus designed to investigate the effects of vitamins $\mathrm{C}$ and/or E on germ cell count and biochemical parameters in experimentally induced cryptorchid rats.

\section{Materials and Methods}

2.1. Animals. Forty (40) male Sprague-Dawley rats (200$250 \mathrm{~g}$ ) were bought in the animal house of the Faculty of Basic Medical Sciences of Ladoke Akintola University of Technology, Ogbomoso, Nigeria, and acclimated to their new environment for two weeks. They were fed a standard laboratory diet (Bova Jay Feeds Nig. Ltd., Ogbomoso) with free access to tap water ad libitum. They were kept under condition of uniform humidity and temperature on a 12h light-dark cycle. Study protocol and animal use were approved, prior to the beginning of the study, by our institutional research and ethical committee. All necessary protocols were followed to ensure the humane treatment of the animals.

2.2. Experimental Protocol. After two weeks of acclimatization to their new environment with standard laboratory diet and water given ad libitum, animals were randomly divided in a blinded fashion into five groups of eight rats each as follows.

Group 1: rats were pretreated with $10 \mathrm{~mL} / \mathrm{kg}$ of vehicle (corn-oil) for 21 days, sham operated on the $22 \mathrm{nd}$ day, and then posttreated with $10 \mathrm{~mL} / \mathrm{kg}$ of vehicle (corn oil) for 7 days.
Group 2: rats were pretreated with $10 \mathrm{~mL} / \mathrm{kg}$ of vehicle for 21 days, rendered unilaterally cryptorchid on the $22 \mathrm{nd}$ day, and then posttreated with $10 \mathrm{~mL} / \mathrm{kg}$ of vehicle for 7 days.

Group 3: rats were pretreated with $75 \mathrm{mg} / \mathrm{kg}$ of vitamin E solution for 21 days, rendered unilaterally cryptorchid on the 22nd day, and then posttreated with $75 \mathrm{mg} / \mathrm{kg}$ of vitamin $\mathrm{E}$ for 7 days.

Group 4: rats were pretreated with $1.25 \mathrm{~g} / \mathrm{kg}$ of vitamin $\mathrm{C}$ solution for 21 days, rendered unilaterally cryptorchid on the 22nd day, and then posttreated with $1.25 \mathrm{~g} / \mathrm{kg}$ of vitamin C solution for 7 days.

Group 5: rats were pretreated with combination of vitamin $\mathrm{E}(75 \mathrm{mg} / \mathrm{kg})$ and vitamin C $(1.25 \mathrm{~g} / \mathrm{kg})$ solutions for 21 days, rendered unilaterally cryptorchid on the 22nd day, and then posttreated with combination of vitamin E $(75 \mathrm{mg} / \mathrm{kg})$ and vitamin C $(1.25 \mathrm{~g} / \mathrm{kg})$ solutions for 7 days.

A solution containing vitamins $\mathrm{E}$ and/or $\mathrm{C}$ dissolved in corn-oil was freshly prepared daily in such a way that all animals received $10 \mathrm{~mL} / \mathrm{kg}$ of either corn-oil alone or the solution depending on the group as described above. The solution or the vehicle was administered by oral gavage between the hour of 9:00 AM and 10:00 AM daily. Corn oil of chemical reagent grade was purchased from Nacalai Tesque, Inc., Japan. It has been conveniently used as one of the most common vehicles to administer lipophilic chemicals to rodents in toxicity studies. It has about $60 \%$ polyunsaturated fatty acid; therefore, it is one of the oils that has been recommended as a replacement for saturated fat [36].

Unilateral cryptorchidism was induced as previously described [37]. Briefly, under strict aseptic conditions, the animals were anaesthetised with ketamine $(75 \mathrm{mg} / \mathrm{kg}$ body weight). The testis was mobilised through a transverse inguinal incision and the gubernacula of the testes severed. The freed testis was pushed back into the abdomen through the internal inguinal ring, which was subsequently closed with 2-0 chromic sutures. The sham operation followed the same procedure, but the testis was left in the scrotum. All the animals subsequently recovered fully.

On the 30th day of the experiment, each rat was weighed and sacrificed by cervical dislocation. Blood sample from each rat was collected (by cardiac puncture) into lithiumheparinized capillary tubes. It was spun using centrifuge at the rate of 3000 revolutions per minute for $15 \mathrm{~min}$. Plasma was collected from each sample and preserved at a very low temperature $\left(-20^{\circ} \mathrm{C}\right)$. The testis of each rat was harvested and preserved in separate formalin bottles. The testis was removed, washed in the washing buffer, and weighed by a standardized method with electronic weighing balance to know the ratio of the homogenizing buffer to the organ. The constituent of the washing buffer is $11.5 \mathrm{~g}$ of $\mathrm{KCl}$ in $1000 \mathrm{~mL}$ of distilled water. The homogenizing buffer $\{\mathrm{pH}=7.4\}$ contains $11.5 \mathrm{~g}$ of $\mathrm{KCl}$ and $7.88 \mathrm{~g}$ of tris $\mathrm{HCl}$ in $1000 \mathrm{~mL}$ of distilled water. $\mathrm{NaOH}$ was added drop wise to correct the $\mathrm{pH}$. The homogenizing buffer was added at a ratio of $1: 4$. The 
testis was ground in the homogenizing buffer, centrifuged, and the homogenate was refrigerated.

2.3. Determination of Germ Cell Count. Germ cell count was done as previously described elsewhere [38]. Briefly, the testis was cut in slabs of about $0.5 \mathrm{~cm}$ thick and fixed in Bouin's fluid for a day after which it was transferred to $70 \%$ alcohol for dehydration. The tissues were passed through 90\% alcohol and chloroform for different durations before they were transferred into two changes of molten paraffin wax for $20 \mathrm{~min}$ each in an oven at $57^{\circ} \mathrm{C}$. Serial sections of $5 \mu \mathrm{m}$ thick were obtained from a solid block of tissue and were stained with haematoxylin and eosin stains, after which they were passed through a mixture of equal concentration of xylene and alcohol. Following clearance in xylene, the tissues were oven-dried. Light microscopy was used for the evaluations. The number of germ cells in 20 cross sections of the seminiferous tubules was counted and taken as the germ cell count.

2.4. Determination of Biochemical Parameters. Superoxide dismutase (SOD) estimation was done by the method described elsewhere [39]. The principle is based on the ability of SOD to inhibit the autooxidation of adrenaline at $\mathrm{pH}$ of 10.2. Superoxide radical $\left\{\mathrm{O}^{-}\right\}$generated causes the oxidation of adrenaline to adrenochrome. The yield of adrenochrome increases per $\mathrm{O}^{-}$introduced with increasing concentration of adrenaline. Briefly, $0.1 \mathrm{~mL}$ of sample was diluted with $0.9 \mathrm{~mL}$ of distilled water. $0.1 \mathrm{~mL}$ of the resulting solution was added to $2.5 \mathrm{~mL}$ of the carbonate buffer. $0.3 \mathrm{~mL}$ of the adrenaline was added. Blank cuvette contained $2.5 \mathrm{~mL}$ of carbonate buffer, $0.3 \mathrm{~mL}$ of adrenaline, and $0.1 \mathrm{~mL}$ of distilled water. The absorbance at $0 \mathrm{sec}$ and $150 \mathrm{sec}$ was read on a spectrophotometer (Jenway Ltd., UK) at wave-length of $480 \mathrm{~nm}$.

Malondialdehyde (MDA) was estimated by the method described elsewhere [40]. The principle is based on the reaction of malondialdehyde (MDA) with thiobarbituric acid (TBA), forming an MDA-TBA complex, which absorbs strongly at a wave-length of $532 \mathrm{~nm}$. Small amounts of MDA are produced during lipid peroxidation, which react with TBA to give a pink colored complex and absorb light when in an acidic solution at $532 \mathrm{~nm}$. Briefly, $0.4 \mathrm{~mL}$ of the sample was mixed with $0.5 \mathrm{~mL}$ of $30 \%$ TCA. $1.6 \mathrm{~mL}$ of Tris $\mathrm{KCl}$ was added. TBA $(0.5 \mathrm{~mL})$ was added and the solution was incubated for 45 mins at $80^{\circ} \mathrm{C}$. This produced pink colored reaction mixtures. The absorbance of the pink supernatant was read at $532 \mathrm{~nm}$ on a spectrophotometer (Jenway Ltd., UK).

Estimation of total protein (TP) was based on the method described elsewhere [41]. One $\mathrm{mL}$ of alkaline sodium carbonate solution was added to $0.05 \mathrm{~mL}$ of plasma and then allowed to stand for $10 \mathrm{~min}$. Folin-Ciocalteu reagent $(0.1 \mathrm{~mL})$ was rapidly added to the mixture and then allowed to stand for $30 \mathrm{~min}$. The absorbance of the blue colour developed was read at $750 \mathrm{~nm}$ on a spectrophotometer (Jenway Ltd., UK). The absorbance of each sample was converted to concentration through extrapolation on a standard protein curve using bovine serum albumin (BSA) as a standard protein.

2.5. Data Processing. Data were analyzed using SPSS version 16.0 for windows. All values given were the mean \pm S.D of the variables measured. Significance was assessed by the analysis of variance (ANOVA) followed by a posthoc Turkey multiple range test for multiple comparisons. $P$ values of 0.05 or less were taken as statistically significant.

\section{Results}

Effects of Vitamins C and/or E on the germ cell count of cryptorchid rat testis are shown in Figure 1. The germ cell count in each of the cryptorchid rat groups was significantly lower $(P<0.001)$ than the noncryptorchid rats. Germ cell count was significantly higher in the vitamin E-treated $(P<$ $0.01)$ and the vitamin $C$-treated $(P<0.05)$ cryptorchid rats than in the vehicle-treated cryptorchid rats. However, there was no significant difference between the germ cell count of the combined vitamin E- and C-treated cryptorchid rats and vehicle-treated cryptorchid rats.

Effects of Vitamins C and/or E on plasma SOD of cryptorchid rat are shown in Figure 2. SOD in each of the cryptorchid rat groups was significantly lower $(P<$ 0.001) than the noncryptorchid rats. Moreover, SOD was significantly higher in the vitamin E-treated $(P<0.01)$ and the vitamin $\mathrm{C}$-treated $(P<0.01)$ cryptorchid rats than in the vehicle-treated cryptorchid rats. However, there was no significant difference between the SOD of the combined vitamin $\mathrm{E}$ - and $\mathrm{C}$-treated cryptorchid rats and the vehicletreated cryptorchid rats.

Figure 3 shows the effects of vitamins $\mathrm{C}$ and/or $\mathrm{E}$ on the plasma MDA of cryptorchid rats. All cryptorchid rats, except those treated with vitamin $\mathrm{C}$, had significantly higher $(P<0.05)$ MDA than the noncryptorchid rats. Moreover, MDA was significantly higher in the vitamin E-treated $(P<$ $0.01)$ and the combined vitamin E- and C-treated $(P<$ $0.05)$ cryptorchid rats than in vehicle-treated cryptorchid rats. However, there was no significant difference $(P>0.05)$ between the MDA of the vitamin C-treated cryptorchid rats and the vehicle treated cryptorchid rats.

Figure 4 shows the effects of vitamins $\mathrm{C}$ and/or $\mathrm{E}$ on the TP of cryptorchid rats. TP in each of the cryptorchid rat groups was significantly lower $(P<0.05, P<0.001)$ than the noncryptorchid rats. Moreover, TP was significantly higher in the vitamin E-treated $(P<0.01)$ and the vitamin $\mathrm{C}$ treated $(P<0.01)$ cryptorchid rats than in the vehicle-treated cryptorchid rats. However, there was no significant difference between the TP of the combined vitamin E- and C-treated cryptorchid rats and vehicle-treated cryptorchid rats.

Figure 5 shows the effects of vitamins $\mathrm{C}$ and/or $\mathrm{E}$ on the testicular weight of cryptorchid rats. The testicular weight in each of the cryptorchid rat groups was significantly lower $(P<0.001)$ than the noncryptorchid rats. Moreover, testicular weight was significantly higher in the vitamin Etreated $(P<0.01)$ and the vitamin $C$-treated $(P<0.05)$ cryptorchid rats than in the vehicle-treated cryptorchid rats. However, there was no significant difference between the 


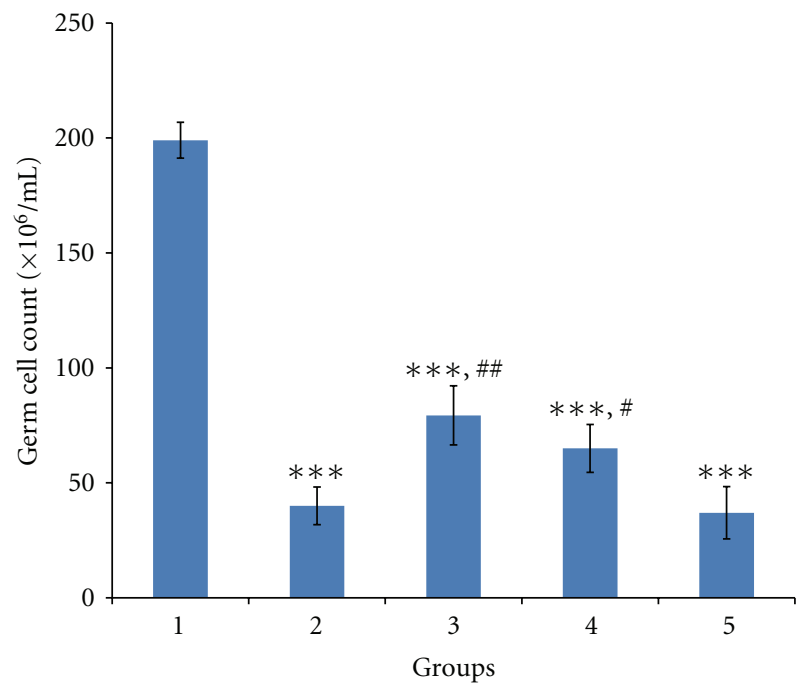

FIGURE 1: Germ cell count in noncryptorchid rats treated with vehicle (1), cryptorchid rats treated with vehicle (2), vitamin E (3), vitamin $C(4)$, and combination of vitamins $E$ and $C(5)$. Values are expressed as mean \pm SEM, $(n=8)$. ${ }^{* *} P<0.001$ versus group 1 ; ${ }^{\#} P<0.05$ and ${ }^{\#} P<0.01$ versus group 2 .

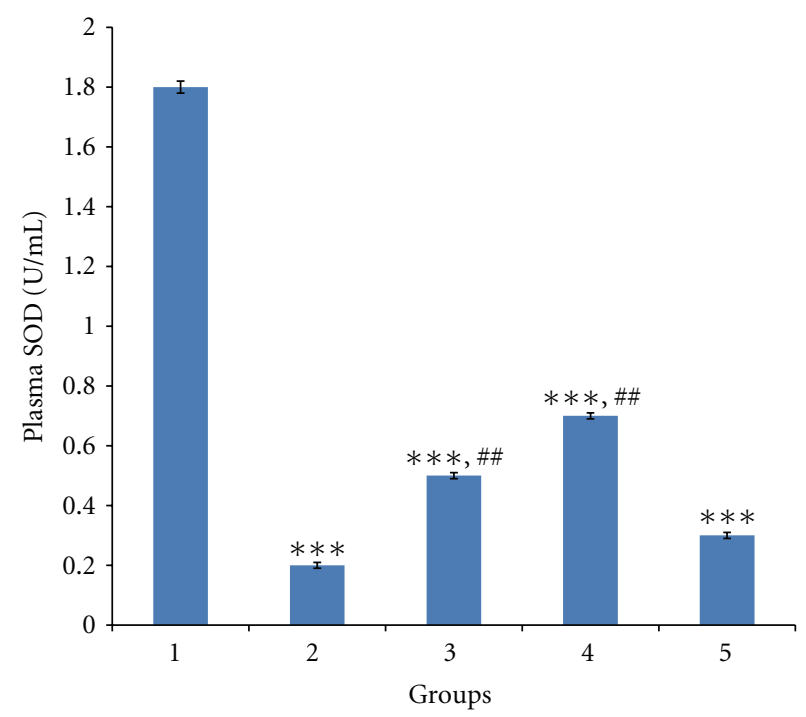

FIgURE 2: Plasma SOD in noncryptorchid rats treated with vehicle (1), cryptorchid rats treated with vehicle (2), vitamin E (3), vitamin $\mathrm{C}(4)$, and combination of vitamins E and C (5). Values are expressed as Mean \pm SEM, $(n=8)$. ${ }^{* * *} P<0.001$ versus group $1 ;{ }^{\# \#} P<0.01$ versus group 2 .

testicular weight of the combined vitamin E- and C-treated cryptorchid rats and vehicle-treated cryptorchid rats.

\section{Discussion}

Interest in the toxicological aspects of oxidative stress has grown in the recent years and research has become increasingly focussed on the mechanistic aspects of oxidative damage and cellular responses in biological systems. Toxic

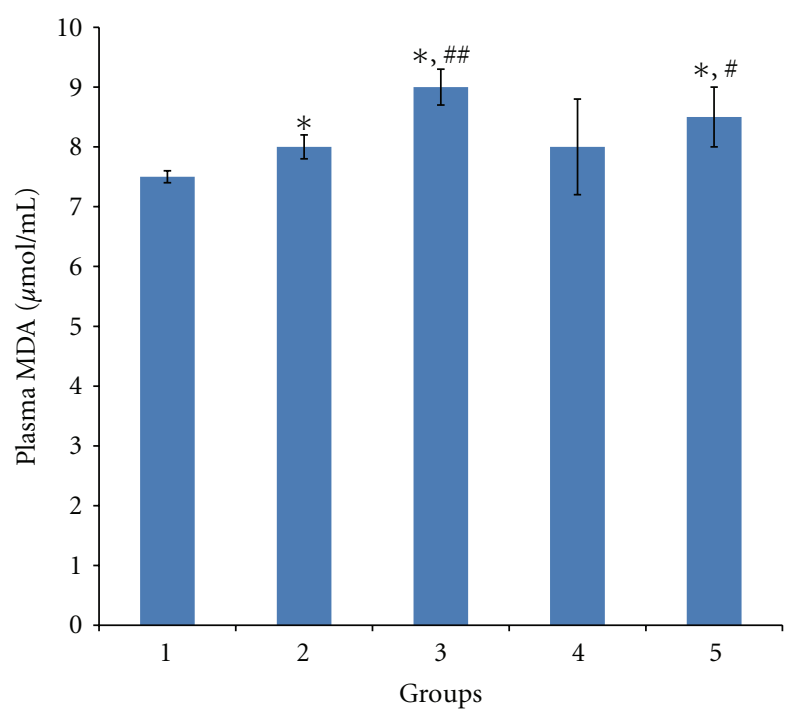

FIGURE 3: Plasma MDA in noncryptorchid rats treated with vehicle (1), cryptorchid rats treated with vehicle (2), vitamin E (3), vitamin $C$ (4), and combination of vitamins $E$ and $C$ (5). Values are expressed as Mean \pm SEM, $(n=8) .{ }^{*} P<0.05$ versus group 1 ; ${ }^{\#} P<0.05$ and ${ }^{\#} P<0.01$ versus group 2 .

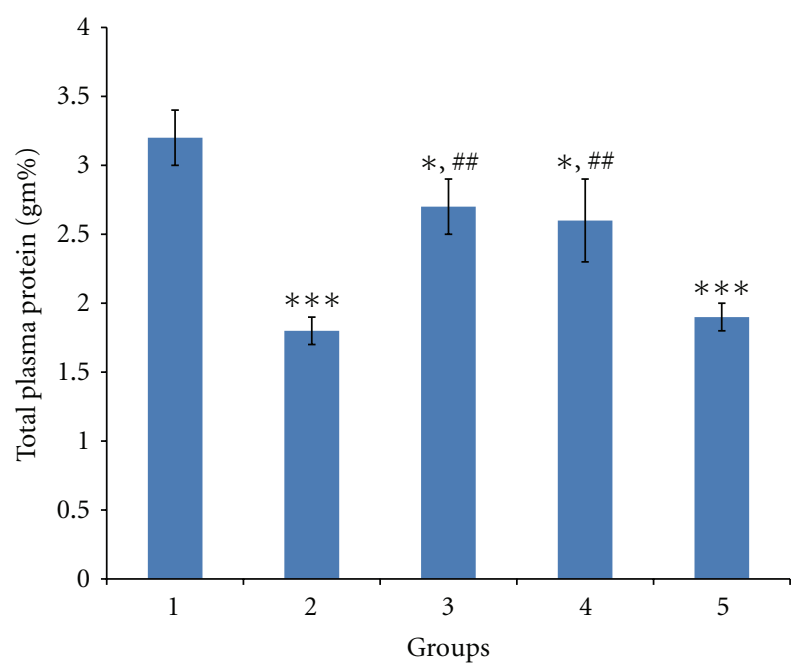

FIGURE 4: Total plasma protein in noncryptorchid rats treated with vehicle (1), cryptorchid rats treated with vehicle (2), vitamin E (3), vitamin $C(4)$, and combination of vitamins $E$ and $C(5)$. Values are expressed as Mean \pm SEM, $(n=8) .{ }^{*} P<0.05,{ }^{* * *} P<0.001$ versus group $1 ;{ }^{\# \#} P<0.01$ versus group 2 .

consequences of oxidative stress at the subcellular level include lipid peroxidation and oxidative damage to DNA and proteins [42]. Typically, mammalian species have been used as models to study oxidative stress and to elucidate the mechanisms underlying cellular damage and response, largely because of the interest in human health issues surrounding oxidative stress [42].

Previous studies in experimental surgically induced cryptorchidism have established that excess generation of 


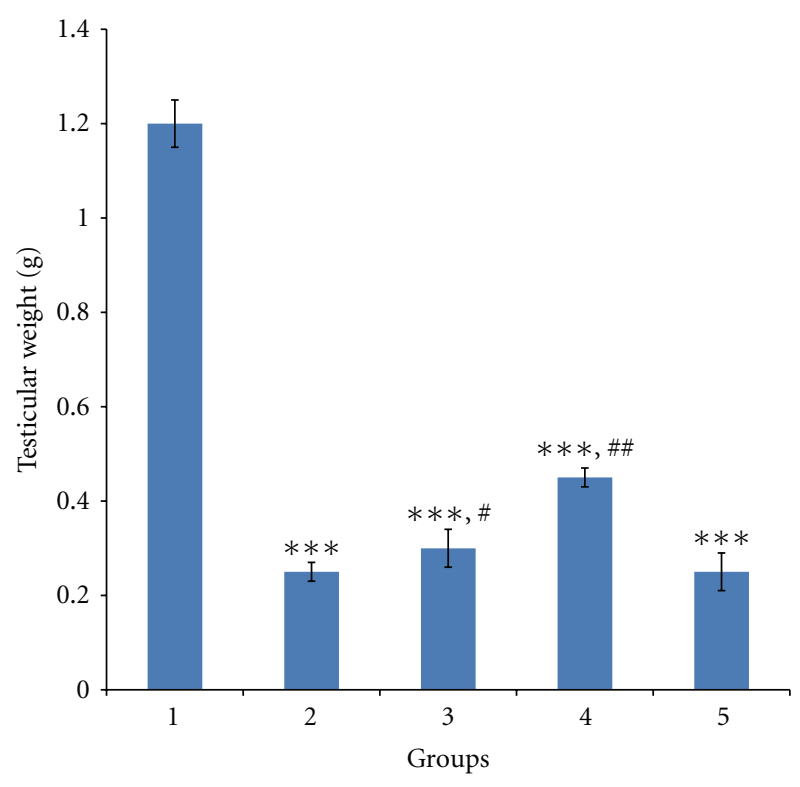

FIGURE 5: Testicular weights in noncryptorchid rats treated with vehicle (1), cryptorchid rats treated with vehicle (2), vitamin E (3), vitamin $C$ (4), and combination of vitamins $E$ and $C(5)$. Values are expressed as Mean \pm SEM, $(n=8)$. ${ }^{* * *} P<0.001$ versus group 1; ${ }^{\#} P<0.05$ and ${ }^{\# \#} P<0.01$ versus group 2 .

free radicals is the underlying causative factor in the pathophysiological manifestations observed in cryptorchidism [15, 33]. Such manifestations as infertility [43], increased rate of apoptosis, germ cell degeneration [44, 45], and malignant transformation [46] have all been attributed to increased oxidative stress.

In the present study, the observed significant elevation of plasma MDA and the reduction of plasma SOD and total protein in the cryptorchid controls are indicative of oxidative stress. Our findings are in agreement with the findings in similar studies which demonstrated lipid peroxidation [33, 47], depletion of antioxidative defences of the body [48], and reduction of total protein [49] as invariable consequences of oxidative stress.

Vitamin E-treated cryptorchid rats had increased plasma protein, SOD, and MDA concentration. The overall results, except the finding of elevation in plasma MDA, confirm the antioxidant properties of vitamin $\mathrm{E}$ which seems to exert by inhibiting xanthine oxidase enzyme system a major source of free radicals in testicular cells $[50,51]$. The elevation of plasma SOD on treatment with vitamin E could be due to a sparing effect on the SOD enzyme system since vitamin $E$ has its own radical scavenging properties [52] and thus augments the anti oxidant capability of the body. Furthermore, other investigators have shown that vitamin $\mathrm{E}$ decreases the release of reactive oxygen species [53] by inhibiting superoxide production [54]. However, the observed increase in the plasma MDA concentration was unexpected as MDA, a marker of lipid peroxidation, was expected to reduce on administration of vitamin $\mathrm{E}$ as has been reported by other investigators $[55,56]$. Some investigators however, have questioned the efficacy of vitamin $\mathrm{E}$ in reducing lipid peroxidation [57-60].
Most studies investigating lipid peroxidation have directly measured the level of peroxidation in the tissues or organs under investigation [55], while our study however, measured the level of peroxidation in the plasma. The mean testicular weight was also found to have increased on treatment with vitamin $\mathrm{E}$, further confirming the salutary effect of vitamin $\mathrm{E}$ in alleviating oxidative stress resulting from cryptorchidism.

Similarly, treatment of cryptorchid rats with vitamin C was found to cause an increase in plasma protein, SOD and, MDA concentrations. Vitamin C being a water soluble antioxidant has the capacity to scavenge both reactive oxygen and nitrogen species, which are thought to play roles in tissue injury [8]. High concentrations of vitamin $\mathrm{C}$ have been found to suppress the activity of superoxide free radicals intracellularly [61]. Vitamin $C$ is known to react with highly aggressive oxidising species directly to produce a much less reactive and recyclable semihydroascorbate [62]. As observed in the vitamin E-treated group, vitamin C did not significantly reduce the MDA concentration. Drake et al. [63] have reported the inability of vitamin $\mathrm{C}$ to reduce MDA concentration in $H$. pylori gastritis. The inability of vitamin $\mathrm{C}$ to reduce lipid peroxidation may be due to its water soluble nature since lipid peroxidation is an outcome of oxidant attack on predominantly lipid soluble cell membranes and structures [64-66].

The animals treated with a combination of vitamins $\mathrm{E}$ and $\mathrm{C}$ showed no evidence of reduction of oxidative stress. The plasma SOD and total protein were not significantly elevated above those of the nontreated cryptorchid control neither did treatment with vitamin $\mathrm{E}$ and $\mathrm{C}$ combination result in appreciable reduction of MDA concentration, which is a marker of lipid peroxidation. These findings were rather unexpected given the widely documented synergistic action of vitamins $\mathrm{E}$ and $\mathrm{C}$. Vitamin $\mathrm{C}$, a water soluble vitamin, is thought to enhance the antioxidant action of vitamin $\mathrm{E}$ by regenerating the protonated tocopherol from the tocopheroxyl radical [9]. Studies done on oxidative stress in respiratory and cardiovascular system have shown that vitamins $\mathrm{E}$ and $\mathrm{C}$ when combined do have the expected synergistic action of reducing free radicals more effectively than when used individually [13, 67-69]. Recently, it was shown that treatment of rats with vitamins C, E and Selenium exerted antioxidant effect and consequently prevented skin damage caused by streptozotocin-induced diabetes [70]. In addition, antioxidant supplementation with vitamins $\mathrm{C}$ and $\mathrm{E}$ reduced the exercise-induced oxidation of proteins in neutrophil, without altering the antioxidant adaptive response as evidenced by the increased Catalase and glutathione peroxidase gene expression [71]. In this study however, we found no such potentiation of antioxidant actions, instead, the two vitamins appeared to have cancelled out each other's actions. This observed difference may be a result of differences in the enzyme systems available for combating oxidative stress in individual organs. Some tissue specific studies have found that vitamin C works more efficiently on its own than when combined with other micronutrients [72-74]. Further studies need to be done in order to elucidate the mechanisms by which they occur. 


\section{Conclusion}

This study provides evidence for the germ cell count boosting and antioxidant potential of vitamins $\mathrm{E}$ and $\mathrm{C}$ when administered separately but not when combined.

\section{References}

[1] K. M. Fairfield and R. H. Fletcher, "Vitamins for chronic disease prevention in adults: scientific review," Journal of the American Medical Association, vol. 287, no. 23, pp. 3116-3126, 2002.

[2] M. C. Polidori, P. Mecocci, S. E. Browne, U. Senin, and M. F. Beal, "Oxidative damage to mitochondrial DNA in Huntington's disease parietal cortex," Neuroscience Letters, vol. 272, no. 1, pp. 53-56, 1999.

[3] M. J. Stampfer, C. H. Hennekens, J. E. Manson, G. A. Colditz, B. Rosner, and W. C. Willett, "Vitamin E consumption and the risk of coronary disease in women," New England Journal of Medicine, vol. 328, no. 20, pp. 1444-1449, 1993.

[4] S. H. Lee, T. Oe, and I. A. Blair, "Vitamin C-induced decomposition of lipid hydroperoxides to endogenous genotoxins," Science, vol. 292, no. 5524, pp. 2083-2086, 2001.

[5] B. Halliwell, "Vitamin C: poison, prophylactic or panacea?" Trends in Biochemical Sciences, vol. 24, no. 7, pp. 255-259, 1999.

[6] M. Meydani, W. J. Evans, G. Handelman et al., "Protective effect of vitamin $\mathrm{E}$ on exercise-induced oxidative damage in young and older adults," American Journal of Physiology, vol. 264, no. 5, pp. R992-R998, 1993.

[7] D. Zhang, S. Okada, Y. Yu, P. Zheng, R. Yamaguchi, and H. Kasai, "Vitamin E inhibits apoptosis, DNA modification, and cancer incidence induced by iron-mediated peroxidation in Wistar rat kidney," Cancer Research, vol. 57, no. 12, pp. 24102414, 1997.

[8] M. S. Cooke, M. D. Evans, I. D. Podmore et al., "Novel repair action of vitamin C upon in vivo oxidative DNA damage," FEBS Letters, vol. 439, no. 3, pp. 363-367, 1998.

[9] K. Sato, E. Niki, and H. Shimasaki, "Free radical-mediated chain oxidation of low density lipoprotein and its synergistic inhibition by vitamin E and vitamin C," Archives of Biochemistry and Biophysics, vol. 279, no. 2, pp. 402-405, 1990.

[10] A. C. Chan, "Partners in defense, vitamin E and vitamin C," Canadian Journal of Physiology and Pharmacology, vol. 71, no. 9, pp. 725-731, 1993.

[11] J. R. Britton, I. D. Pavord, K. A. Richards et al., "Dietary antioxidant vitamin intake and lung function in the general population," American Journal of Respiratory and Critical Care Medicine, vol. 151, no. 5, pp. 1383-1387, 1995.

[12] M. Meydani, W. J. Evans, G. Handelman et al., "Protective effect of vitamin $\mathrm{E}$ on exercise-induced oxidative damage in young and older adults," American Journal of Physiology, vol. 264, no. 5, pp. R992-R998, 1993.

[13] J. T. Salonen, K. Nyyssönen, R. Salonen et al., "Antioxidant Supplementation in Atherosclerosis Prevention (ASAP) study: a randomized trial of the effect of vitamins $\mathrm{E}$ and $\mathrm{C}$ on 3year progression of carotid atherosclerosis," Journal of Internal Medicine, vol. 248, no. 5, pp. 377-386, 2000.

[14] H. N. Lim, E. Rajpert-De Meyts, N. E. Skakkebæk, J. R. Hawkins, and I. A. Hughes, "Genetic analysis of the INSL3 gene in patients with maldescent of the testis," European Journal of Endocrinology, vol. 144, no. 2, pp. 129-137, 2001.
[15] M. Ahotupa and I. Huhtaniemi, "Impaired detoxification of reactive oxygen and consequent oxidative stress in experimentally cryptorchid rat testis," Biology of Reproduction, vol. 46, no. 6, pp. 1114-1118, 1992.

[16] A. L. Villumsen and B. Zachau-Christiansen, "Spontaneous alterations in position of the testes," Archives of Disease in Childhood, vol. 41, no. 216, pp. 198-200, 1966.

[17] P. E. Ansell, V. Bennet, D. Bull et al., "Cryptorchidism: a prospective study of 7500 consecutive male births, 1984-8," Archives of Disease in Childhood, vol. 67, no. 7, pp. 892-899, 1992.

[18] K. Sijstermans, W. W. M. Hack, L. M. Van Der VoortDoedens, R. W. Meijer, and K. Haasnoot, "Puberty stage and spontaneous descent of acquired undescended testis: implications for therapy?" International Journal of Andrology, vol. 29, no. 6, pp. 597-602, 2006.

[19] H. E. Virtanen and J. Toppari, "Epidemiology and pathogenesis of cryptorchidism," Human Reproduction Update, vol. 14, no. 1, pp. 49-58, 2008.

[20] G. S. Berkowitz, R. H. Lapinski, S. E. Dolgin, J. G. Gazella, C. A. Bodian, and I. R. Holzman, "Prevalence and natural history of cryptorchidism," Pediatrics, vol. 92, no. 1, pp. 44-49, 1993.

[21] K. A. Boisen, M. Kaleva, K. M. Main et al., "Difference in prevalence of congenital cryptorchidism in infants between two Nordic countries," The Lancet, vol. 363, no. 9417, pp. 1264-1269, 2004.

[22] B. Buemann, H. Henriksen, A. L. Villumsen, A. Westh, and B. Zachau-Christiansen, "Incidence of undescended testis in the newborn," Acta Chirurgica Scandinavica. Supplementum, vol. 283, pp. 289-293, 1961.

[23] P. Ghirri, C. Ciulli, M. Vuerich et al., "Incidence at birth and natural history of cryptorchidism: a study of 10,730 consecutive male infants," Journal of Endocrinological Investigation, vol. 25, no. 8, pp. 709-715, 2002.

[24] V. K. Mital and B. K. Garg, "Undescended testicle," The Indian Journal of Pediatrics, vol. 39, no. 5, pp. 171-174, 1972.

[25] R. T. Preikša, B. Žilaitiene, V. Matulevičius et al., "Higher than expected prevalence of congenital cryptorchidism in Lithuania: a study of 1204 boys at birth and 1 year follow-up," Human Reproduction, vol. 20, no. 7, pp. 1928-1932, 2005.

[26] C. G. Scorer, "The descent of the testis," Archives of Disease in Childhood, vol. 39, pp. 605-609, 1964.

[27] M. K. Thong, C. T. Lim, and H. Fatimah, "Undescended testes: incidence in 1002 consecutive male infants and outcome at 1 year of age," Pediatric Surgery International, vol. 13, no. 1, pp. 37-41, 1998.

[28] R. C. Benson, C. M. Beard, P. P. Kelalis, and L. T. Kurland, "Malignant potential of the cryptorchid testis," Mayo Clinic Proceedings, vol. 66, no. 4, pp. 372-378, 1991.

[29] C. Krausz, L. Quintana-Murci, M. Fellous, J. P. Siffroi, and K. McElreavey, "Absence of mutations involving the INSL3 gene in human idiopathic cryptorchidism," Molecular Human Reproduction, vol. 6, no. 4, pp. 298-302, 2000.

[30] S. P. Chaki, M. M. Misro, D. Ghosh, D. K. Gautam, and M. Srinivas, "Apoptosis and cell removal in the cryptorchid rat testis," Apoptosis, vol. 10, no. 2, pp. 395-405, 2005.

[31] T. T. Turner, H. J. Bang, and J. J. Lysiak, "Experimental testicular torsion: reperfusion blood flow and subsequent testicular venous plasma testosterone concentrations," Urology, vol. 65, no. 2, pp. 390-394, 2005.

[32] M. M. Misro, S. P. Chaki, and D. K. Gautam, "Germ cell death and their removal during initial stages of testicular ischemia 
and cryptorchidism: a comparative analysis," Indian Journal of Experimental Biology, vol. 43, no. 11, pp. 1080-1087, 2005.

[33] V. Peltola, I. Huhtaniemi, and M. Ahotupa, "Abdominal position of the rat testis is associated with high level of lipid peroxidation," Biology of Reproduction, vol. 53, no. 5, pp. 11461150, 1995.

[34] Y. C. Li, X. Q. Hu, L. J. Xiao et al., "An oligonucleotide microarray study on gene expression profile in mouse testis of experimental cryptorchidism," Frontiers in Bioscience, vol. 11, no. 2, pp. 2465-2482, 2006.

[35] M. Ikeda, H. Kodama, J. Fukuda et al., "Role of radical oxygen species in rat testicular germ cell apoptosis induced by heat stress," Biology of Reproduction, vol. 61, no. 2, pp. 393-399, 1999.

[36] J. Dupont, P. J. White, M. P. Carpenter et al., "Food uses and health effects of corn oil," Journal of the American College of Nutrition, vol. 9, no. 5, pp. 438-470, 1990.

[37] A. O. Afolabi, O. Aluko, O. Oyewopo, B. M. Olabinri, O. Olotu, and Y. Raji, "Trino IB ameliorates the oxidative stress of cryptorchidism in the rat," African Journal of Biotechnology, vol. 8, no. 7, pp. 1183-1187, 2009.

[38] A. O. Akpantah, A. A. Oremosu, M. O. Ajala, C. C. Noronha, and A. O. Okanlawon, "The effect of crude extract of Garcinia kola seed on the histology and hormonal milieu of male Sprague-Dawley rats' reproductive organs," Nigerian Journal of Health and Biomedical Sciences, vol. 2, no. 1, pp. 40-46, 2003.

[39] H. P. Misra and I. Fridovich, "The role of superoxide anion in the autoxidation of epinephrine and a simple assay for superoxide dismutase," Journal of Biological Chemistry, vol. 247, no. 10, pp. 3170-3175, 1972.

[40] H. Ohkawa, N. Ohishi, and K. Yagi, "Assay for lipid peroxides in animal tissues by thiobarbituric acid reaction," Analytical Biochemistry, vol. 95, no. 2, pp. 351-358, 1979.

[41] O. H. Lowry, N. J. Rosebrough, A. L. Farr, and R. J. Randall, "Assay of Protein, the original method," Journal of Biological Chemistry, vol. 193, p. 265, 1951.

[42] H. Sies, "Strategies of antioxidant defense," European Journal of Biochemistry, vol. 215, no. 2, pp. 213-219, 1993.

[43] W. O. Nelson, "Mammalian spermatogenesis: effects of experimental cryptorchidism in the rat and non-descent of the testis in man," Recent Progress in Hormone Research, vol. 6, pp. 29 62, 1951.

[44] T. Shikone, H. Billig, and A. J. W. Hsueh, "Experimentally induced cryptorchidism increases apoptosis in rat testis," Biology of Reproduction, vol. 51, no. 5, pp. 865-872, 1994.

[45] K. Henriksen, H. Hakovirta, and M. Parvinen, "In-situ quantification of stage-specific apoptosis in the rat seminiferous epithelium: effects of short-term experimental cryptorchidism," International Journal of Andrology, vol. 18, no. 5, pp. 256-262, 1995.

[46] J. R. Davis and C. F. Firlit, "The germinal epithelium of cryptorchid testes experimentally induced in prepubertal and adult rats," Fertility and Sterility, vol. 17, no. 2, pp. 187-200, 1966.

[47] H. Kimura, Y. Yamada, Y. Morita, H. Ikeda, and T. Matsuo, "Dietary ascorbic acid depresses plasma and low density lipoprotein lipid peroxidation in genetically scorbutic rats," Journal of Nutrition, vol. 122, no. 9, pp. 1904-1909, 1992.

[48] R. Radi, J. S. Beckman, K. M. Bush, and B. A. Freeman, "Peroxynitrite-induced membrane lipid peroxidation: the cytotoxic potential of superoxide and nitric oxide," Archives of Biochemistry and Biophysics, vol. 288, no. 2, pp. 481-487, 1991.
[49] A. Rehman, C. S. Collis, M. Yang et al., "The effects of iron and vitamin C co-supplementation on oxidative damage to DNA in healthy volunteers," Biochemical and Biophysical Research Communications, vol. 246, no. 1, pp. 293-298, 1998.

[50] T. Koizumi and Z. G. Li, "Role of oxidative stress in single-dose, cadmium-induced testicular cancer," Journal of Toxicology and Environmental Health, vol. 37, no. 1, pp. 25-36, 1992.

[51] Ö. Yaman, T. Soygür, E. Yilmaz, S. Elgün, A. Keskinege, and O. Gögüş, "The significance of testicular reactive oxygen species on testicular histology in infertile patients," International Urology and Nephrology, vol. 31, no. 3, pp. 395-399, 1999.

[52] M. Meydani, "Vitamin E," The Lancet, vol. 345, no. 8943, pp. 170-174, 1995.

[53] S. Devaraj, D. Li, and I. Jialal, "The effects of alpha tocopherol supplementation on monocyte function: decreased lipid oxidation, interleukin $1 \beta$ secretion, and monocyte adhesion to endothelium," Journal of Clinical Investigation, vol. 98, no. 3, pp. 756-763, 1996.

[54] L. J. Van Tits, P. N. Demacker, J. De Graaf, H. L. HakLemmers, and A. F. Stalenhoef, " $\alpha$-Tocopherol supplementation decreases production of superoxide and cytokines by leukocytes ex vivo in both normolipidemic and hypertriglyceridemic individuals," American Journal of Clinical Nutrition, vol. 71, no. 2, pp. 458-464, 2000.

[55] N. Ferré, J. Camps, A. Paul et al., "Effects of high-fat, lowcholesterol diets on hepatic peroxidation and antioxidants in apolipoprotein E-deficient mice," Molecular and Cellular Biochemistry, vol. 218, no. 1-2, pp. 165-169, 2001.

[56] A. H. Goldfarb, M. K. McIntosh, B. T. Boyer, and J. Fatouros, "Vitamin E effects on indexes of lipid peroxidation in muscle from DHEA- treated and exercised rats," Journal of Applied Physiology, vol. 76, no. 4, pp. 1630-1635, 1994.

[57] E. A. Meagher, O. P. Barry, J. A. Lawson, J. Rokach, and G. A. FitzGerald, "Effects of vitamin E on lipid peroxidation in healthy persons," Journal of the American Medical Association, vol. 285, no. 9, pp. 1178-1182, 2001.

[58] M. Reilly, N. Delanty, J. A. Lawson, and G. A. FitzGerald, "Modulation of oxidative stress invivo in chronic cigarette smokers," Circulation, vol. 94, no. 1, pp. 19-25, 1996.

[59] B. E. Leibovitz, M. L. Hu, and A. L. Tappel, "Lipid peroxidation in rat tissue slices: effect of dietary vitamin E, corn oil-lard and menhaden oil," Lipids, vol. 25, no. 3, pp. 125-129, 1990.

[60] G. Palumbo, F. Avanzini, C. Alli et al., "Effects of vitamin E on clinic and ambulatory blood pressure in treated hypertensive patients," American Journal of Hypertension, vol. 13, no. 5, pp. 564-567, 2000.

[61] C. G. Moertel, T. R. Fleming, and E. T. Creagan, "High-dose vitamin $C$ versus placebo in the treatment of patients with advanced cancer who have had no prior chemotherapy. A randomized double-blind comparison," New England Journal of Medicine, vol. 312, no. 3, pp. 137-141, 1985.

[62] G. R. Buettner and P. L. Moseley, "EPR spin trapping of free radicals produced by bleomycin and ascorbate," Free Radical Research Communications, vol. 19, no. 1, pp. S89-S93, 1993.

[63] I. M. Drake, N. P. Mapstone, C. J. Schorah et al., "Reactive oxygen species activity and lipid peroxidation in Helicobacter pylori associated gastritis: relation to gastric mucosal ascorbic acid concentrations and effect of $\mathrm{H}$ pylori eradication," Gut, vol. 42, no. 6, pp. 768-771, 1998.

[64] J. A. North, A. A. Spector, and G. R. Buettner, "Cell fatty acid composition affects free radical formation during lipid peroxidation," American Journal of Physiology, vol. 267, no. 1, pp. C177-C188, 1994. 
[65] L. S. Alexander-North, J. A. North, K. P. Kiminyo, G. R. Buettner, and A. A. Spector, "Polyunsaturated fatty acids increase lipid radical formation induced by oxidant stress in endothelial cells," Journal of Lipid Research, vol. 35, no. 10, pp. 1773-1785, 1994.

[66] H. Kappus, "Lipid peroxidation: mechanisms, enzymology and biological relevance," in Oxidative Stress, H. Sies, Ed., pp. 273-310, Academic Press, New York, NY, USA, 1985.

[67] J. Chaudière and R. Ferrari-Iliou, "Intracellular antioxidants: from chemical to biochemical mechanisms," Food and Chemical Toxicology, vol. 37, no. 9-10, pp. 949-962, 1999.

[68] A. C. Carr, B. Z. Zhu, and B. Frei, "Potential antiatherogenic mechanisms of ascorbate (vitamin C) and $\alpha$-tocopherol (vitamin E)," Circulation Research, vol. 87, no. 5, pp. 349-354, 2000.

[69] N. S. Dhalla, R. M. Temsah, and T. Netticadan, "Role of oxidative stress in cardiovascular diseases," Journal of Hypertension, vol. 18 , no. 6, pp. 655-673, 2000 .

[70] B. Sokmen, H. Basaraner, and R. Yanardag, "Combined effects of treatment with vitamin $\mathrm{C}$, vitamin $\mathrm{E}$ and selenium on the skin of diabetic rats," Human \& Experimental Toxicology. In press.

[71] A. Sureda, M. D. Ferrer, A. Mestre, J. A. Tur, and A. Pons, "Vitamins $\mathrm{C}$ and $\mathrm{E}$ diet supplementation prevents neutrophil protein oxidation without affecting the adaptative response to exercise," International Journal of Sport Nutrition and Exercise Metabolism. In press.

[72] A. Ascherio, E. B. Rimm, M. A. Hernán et al., "Relation of consumption of vitamin E, vitamin $\mathrm{C}$, and carotenoids to risk for stroke among men in the United States," Annals of Internal Medicine, vol. 130, no. 12, pp. 963-970, 1999.

[73] L. H. Kushi, A. R. Folsom, R. J. Prineas, P. J. Mink, Y. Wu, and R. M. Bostick, "Dietary antioxidant vitamins and death from coronary heart disease in postmenopausal women," New England Journal of Medicine, vol. 334, no. 18, pp. 1156-1162, 1996.

[74] H. N. Hodis, W. J. Mack, L. LaBree et al., "Serial coronary angiographic evidence antioxidant vitamin intake reduces progression of coronary artery atherosclerosis," Journal of the American Medical Association, vol. 273, no. 23, pp. 1849-1854, 1995. 

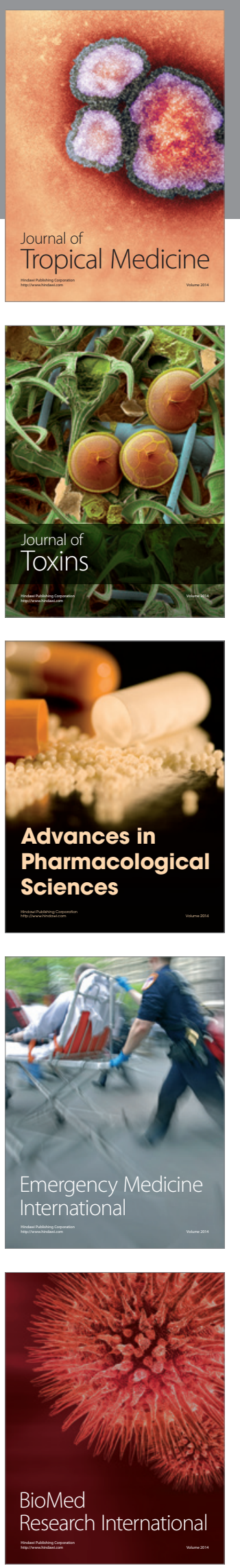
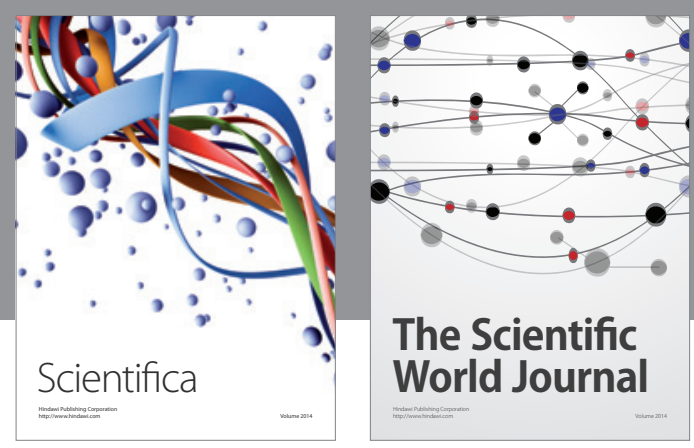

The Scientific World Journal
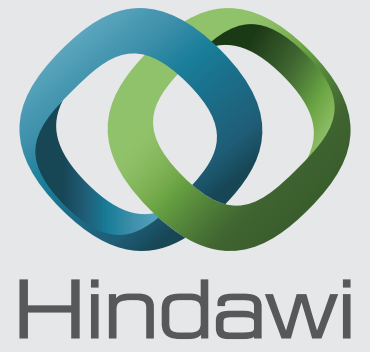

Submit your manuscripts at

http://www.hindawi.com
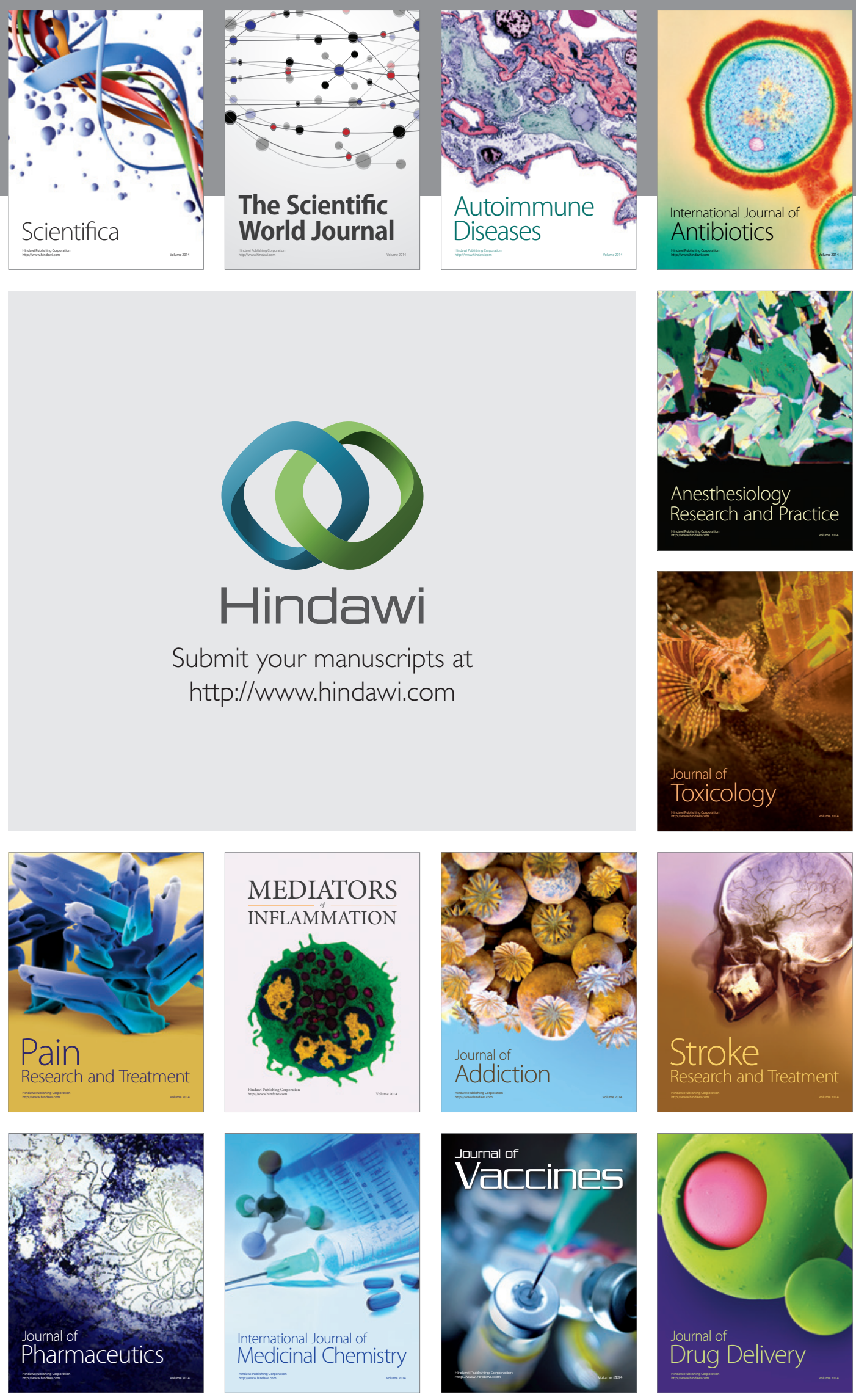